\title{
The Impact of the Level of Inventories on Corporate Profits in E-Commerce Companies in Poland
}

\author{
Grzegorz Michalski, Emilia Brożyna*
}

\begin{abstract}
Purpose - The main purpose of the paper is a scientific discussion about the influence of stock level on profits of enterprises selling online in Poland. This article explores the domain of inventory levels and their impact on capital and other financial management issues in e-commerce companies.

Design/methodology/approach - The test procedure is based on the method of a multiple case study research. The subject of the research is companies that sell online in Poland. In the project descriptive methods regarding statistics and the financial analysis are mainly used. Crucial is access to data from the financial statements of the Amadeus database. Achieving the targets have been used in literature studies, in particular, Polish and English-language economics literature.

Findings - The level of inventories has a large significance for the profits and losses of e-commerce companies. Nevertheless, the profits of companies selling online do not differ significantly on the background of the entire industry.

Originality/value - The project can be used to build and to evaluate scientific issues related to the integration of capital structure management, and other financial management issues in organizations. The proposed research is also of great importance for the use of theoretical empirical data collected during the project. They can also serve as a basis to correct the theoretical model of performance management in companies. The research will aim at contributing to a better understanding of issues associated with the influence of factors that determine economical efficiency.
\end{abstract}

Keywords: e-commerce, online sale, internet, inventory management, stock

\section{Introduction}

Inventory levels are connected with a firm strategy in current assets. Moneys tied in current assets levels are a burden for the firm, which uses them. So there is an opinion that current assets levels should be as small as possible. Money tied in inventories means capital requirements. Capital requirements are connected with opportunity costs that are reflected in higher - because of that - cost of capital. Cost of capital rate is a result not only a level of invested capital but also risk. That risk is higher when a firm faces the possibility of a lack of inventories. In e-commerce firms there is a need to answer an order which is reasonable

\footnotetext{
* dr hab. Grzegorz Michalski prof. UE, Uniwersytet Ekonomiczny we Wrocławiu, Wydział Inżynieryjno-Ekonomiczny, Katedra Pracy i Kapitału, e-mail: grzegorz.michalski@ue.wroc.pl; mgr Emilia Brożyna, doktorant, Uniwersytet Ekonomiczny we Wrocławiu, Wydział Inżynieryjno-Ekonomiczny, Katedra Pracy i Kapitału, emilia.brozyna@ ue.wroc.pl.
} 
and accepted by its customers or client time and manner. That is the most important point for the success of the whole business. Without a sale that suits to customers' requirements there is no business at all! No financial tricks help when there is no value creation at the very beginning point of an operational cycle: sale. The Internet has been available in Poland since 26 September 1990. Then the first internet-speed analogue was launched. Two decades have passed since the pioneering attempts at the Institute of Nuclear Physics in Cracow, the Internet has now become a tool of mass communication, used by more than $70 \%$ of the population. In a modern economy networks offer a wide range of possibilities. One of the most important is their widespread use in online sales. This form of transaction is used by several companies treating the internet as an additional sales market. There are also a number of Internet companies, whose activities are fully based on functioning in virtual reality. Consumers are also interested in online trading as this encourages them to save money and time.

The World Wide Web (WWW) significantly affected the way consumers buy goods and services. Thanks to the Internet, they gather information, compare products, and seek an opinion on the product or service (lo Storto 2013, p. 1004). There are more entrepreneurs and consumers with more interest and courage to discover the possibilities offered by the internet. Modern technology economy remains the economy by client. It is the customer who decides whether or not to carry out transactions through new distribution channels and it is the main drive for their development.

\section{E-commerce as a new channel}

The higher risk of e-commerce firms is a result of the relatively higher probability of financial difficulties than in the case of those without e-commerce. The risk is the probability of obtaining a result other than the one expected (but the probability of obtaining a result worse than expected is called a threat, and the probability of a result that is better-than-expected is an opportunity). Incurring such risks by the capital donor is accompanied by the need to increase the cost of capital by the bonus for risk. The costs of agency conflicts for e-commerce enterprises are higher than those found in enterprises without e-commerce. Agency costs are incurred in connection with the existence of the agency problem and the result of the need to monitor agents by the enterprise - in the Internet many depend on infrastructure suppliers who can easy fail. Another aspect of agency costs is all kinds of costs arising from creditors who protect themselves against owner's actions that are adverse to them. Companies that use e-commerce usually operate in areas that are connected with new technologies. Changes in that business environment influence the risk of the enterprise and the suppliers of the capital want a higher premium for additional risk. Smaller amounts of information about all risks during e-commerce sales available to enterprises using e-commerce compared to information from other entities results in an increase in the cost of external capital. This phenomenon is called information asymmetry. It occurs when the various parties to the transaction (e.g., debtor and creditor) have different information on the subject relevant to 
the transaction (e.g. on the risk associated with the company). Electronic commerce (e-commerce, e-commerce) as defined by the Polish Central Statistical Office includes transactions carried out by the network. They can be based on IP or other computer networks. Goods and services are ordered over those networks, but the payment and the ultimate delivery of the ordered goods can be made in or outside the network. Such transactions may be made between the following entities: businesses, individual people, government agencies or other organizations, public and private. It is worth noting that according to this definition, orders received by telephone, fax or e-mail are not a part of e-commerce (GUS 2013).

M. Silver De Kare shows internet sales as a way of doing business between trading partners in cyberspace (De Kare 2002, p. 80). According to Kraska e-commerce is commercial transactions via telecommunication networks, coupled with making payments for goods and services. This takes place without direct contact between the parties (Kraska 2004, p. 66).

The literature describes the Internet and e-commerce as an indispensable element of the development process (Lawrence 2013, p. 152). E-commerce is associated with production and the sale of goods by modern information and communication technologies (Szopiński 2013, p. 32). Each transaction conducted over the internet is the result of steps:

- search,

- order,

- payment,

- delivery.

Convergence between online and offline is facilitated by modern technological interfaces such as mobiles and tablets (Harwood 2012, p. 17). There are in the literature a division into two models of e-commerce: pure and mixed. Model pure means buying a product or service in a digital form and its delivery to the customer and the processing of transactions also has a digital character. When any of these elements take the form of an individual, it is a mixed type of e-commerce (Żurak-Owczarek 2011, p. 170).

\section{E-commerce inventory management in Poland}

Poland has a large market of online sales in Europe. E-commerce is becoming an important and rapidly growing sector of the Polish economy. Still we can observe considerable, double-digit growth of sales via the Internet. So significant development cannot be seen in mature countries like the United Kingdom and Germany, which are very large, but do not grow quite as fast. The primary objective of inventory management in an enterprise is to maintain their lowest possible level, because their possession is associated with the freezing of capital. At the same time, however, very low levels of inventory may adversely affect the level of sales by interference with the production process or the mere absence of finished products while there are a buyers willing to buy them (disappointed, they can turn with their demand to the competition). The freezing of capital contributes to the reduction of the enterprise value, as it negatively impacts the level of cash flow. The reduction in revenues from sales also 
destroys the value of the enterprise for its owner due to lower projected cash flows. Multiple methods are used in order to optimize inventory levels in the enterprise. The purpose of inventory management in an enterprise should take into account the interests of business owners, and minimizing inventory levels must occur, taking into account the demand for stocks resulting from the need to continue to implement the operating cycle of the enterprise and the relationship between the level of inventories and the value of the enterprise must be taken into account. The XYZ method is a simple method for inventory monitoring used in the process of inventory monitoring, allowing minimizing the cost of the process. The main idea is to divide the inventory held in the enterprise into three groups, marked as $\mathrm{X}, \mathrm{Y}, \mathrm{Z}$. Group $\mathrm{X}$ includes the stocks of major importance for an average enterprise; these stocks are often associated with major investments, whose deficiency is associated with a high risk for enterprise's reputation and costs. Generally it is relatively the smallest group of stocks in an enterprise, but also the most attention is paid to it. Group Y is the intermediate stocks. Group $\mathrm{Z}$ includes cheap stocks or stocks that are easy to replace. It is the most numerous categories of stocks but its importance is the smallest. The least time is devoted to the monitoring of this group and most often in the case of this group it is sufficient to apply the method of red line or two bins. The method of the green line is a simple method of determining the point of time of order for a further supply of materials used for group $Z$ materials. The idea is that group $\mathrm{Z}$ materials are stored in a suitable room (or container) and as they are used their level decreases. If the stock drops sufficiently, the green line is unveiled indicating the need to place an order. The method of two baskets (called the two-bin method) is that the materials are placed in two containers. The need to place an order is indicated when stocks run out of one of them. During the order the execution inventory from the second container are used (which is a reserve supply). Depletion of the second container is another signal and at the same time the beginning of the use of materials in the first container (which has already been complemented). In order to monitor the inventory of group $\mathrm{X}$ more complex models should be used, such as the optimal size of the contract model and the optimal production quantity model. Simple methods of inventory management, including the discussed XYZ method, are characterized by the low cost of implementation while maintaining very high efficiency in the case of micro, small or medium-sized enterprises. In more complex cases, such methods may not be sufficient, but the innovative approach to the application of simple methods often greatly simplifying inventory management process, may contribute much more to the growth of an enterprise's value than trying to implement more complex and expensive methods. One from the mentioned solutions is the Wilson Model based economic order quantity model that is an inventory management model in which the optimal delivery size is assumed, guaranteeing minimizing total inventory costs. According to that model, we should expect that in e-commerce firms the game between the levels of inventories, costs of the lack of inventories and costs of holding them is more influential than in firms that are not connected with e-commerce. The value of stocks in companies that deal in e-commerce 
is characterized by a growing trend. The average levels of inventories in companies selling online in Poland are presented in Figure 1.

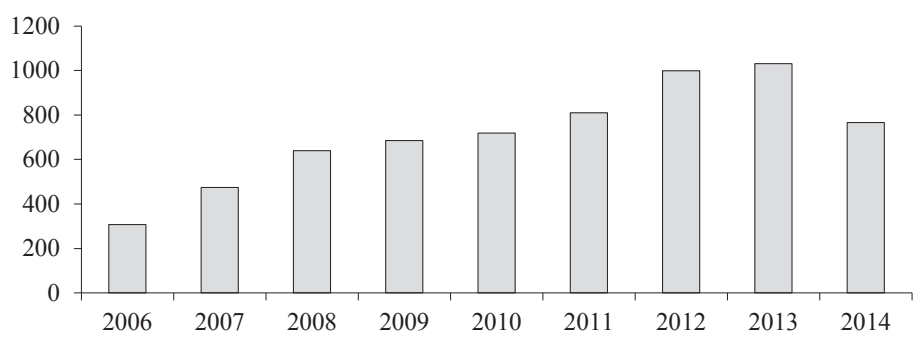

Figure 1. Stock in companies selling online in Poland (in thousands of Euro)

Source: own study based on data from the database Amadeus.

Only in 2014, there is a noticeable decline in the volume of inventories in e-commerce companies. In 2013, when there is the biggest value, the level of stock more than tripled in comparison to 2006 .

Table 1

T-student test sock vs. P/L before tax

\begin{tabular}{|l|r|l|l|l|r|r|}
\hline Year & Different & $\begin{array}{l}\text { St. Dev. } \\
\text { Different }\end{array}$ & $\mathrm{t}$ & $\mathrm{p}$ & -95\% CI & $+95 \%$ CI \\
\hline 2014 & 628.773 & $1,939.783$ & 4.074450 & 0.000073 & 323.960 & 933.586 \\
2013 & 800.773 & $3,212.982$ & 3.132778 & 0.002066 & 295.893 & $1,305.653$ \\
2012 & $1,170.559$ & $4,053.442$ & 3.629929 & 0.000383 & 533.611 & $1,807.508$ \\
2011 & 761.666 & $3,781.419$ & 2.531851 & 0.012329 & 167.463 & $1,355.869$ \\
2010 & 661.063 & $2,859.915$ & 2.905483 & 0.004197 & 211.663 & $1,110.463$ \\
2009 & 466.015 & $2,688.747$ & 2.178606 & 0.030852 & 43.512 & 888.518 \\
2008 & 381.316 & $2,108.810$ & 2.272878 & 0.024390 & 49.943 & 712.689 \\
2007 & 216.037 & $1,909.018$ & 1.422481 & 0.156870 & -83.942 & 516.015 \\
2006 & 95.232 & $1,152.512$ & 1.038636 & 0.300571 & -85.872 & 276.335 \\
\hline
\end{tabular}

Source: own study based on data from the database Amadeus.

In the period 2008-2014 there is a relationship between the size of reserves and profits and loss before tax. The results showed that the mean values in e-commerce companies are statistically significant. Only in the first two years do the results indicate no significance. This may be due to the low popularity of e-commerce compared to today.

After the results obtained in the first table, it is important to investigate whether the size of its profits differs significantly between e-commerce companies and all firms selling in the country. These data are presented in Table 2. 
Table 2

T-student test $\mathrm{P} / \mathrm{L}$ before tax e-commerce vs. industry

\begin{tabular}{lcllllllr}
\hline Year & $\begin{array}{l}\text { Average } \\
\text { e-commerce }\end{array}$ & $\begin{array}{l}\text { Average } \\
\text { industry }\end{array}$ & \multicolumn{1}{l}{$\mathrm{T}$} & $\mathrm{P}$ & $\begin{array}{l}\text { St. Dev. } \\
\text { e-commerce }\end{array}$ & $\begin{array}{l}\text { ST. Dev. } \\
\text { industry }\end{array}$ & $-95 \% \mathrm{CI}$ & \multicolumn{1}{c}{$+95 \% \mathrm{CI}$} \\
\hline 2014 & 137.854 & 204.7720 & -0.15551 & 0.876428 & 750.911 & $5,406.743$ & -910.55 & 776.714 \\
2013 & 229.509 & 231.2661 & -0.00323 & 0.997419 & $1,696.050$ & $6,820.304$ & $-1,066.73$ & $1,063.211$ \\
2012 & -171.622 & 210.3010 & -0.80756 & 0.419384 & $2,994.257$ & $5,918.262$ & $-1,309.09$ & 545.248 \\
2011 & 47.605 & 237.7014 & -0.47245 & 0.636629 &, 3033.015 & $5,025.955$ & -978.92 & 598.725 \\
2010 & 57.316 & 296.1358 & -0.70790 & 0.479042 & $1,859.325$ & $4,226.217$ & -900.21 & 422.570 \\
2009 & 218.761 & 234.1610 & -0.05359 & 0.957268 & $1,207.757$ & $3,605.182$ & -578.82 & 548.021 \\
2008 & 258.802 & 254.4695 & 0.01762 & 0.985946 & $1,104.501$ & $3,084.455$ & -477.84 & 486.505 \\
2007 & 291.343 & 276.4375 & 0.06708 & 0.946518 & $1,015.555$ & $2,786.338$ & -420.70 & 450.509 \\
2006 & 211.290 & 174.5347 & 0.26428 & 0.791579 & 645.972 & $1,743.962$ & -235.91 & 309.419 \\
\hline
\end{tabular}

Source: own study based on data from the database Amadeus.

Differences in the size of the profits and loss of the e-commerce companies compared to the entire industry in Poland are not statistically significant. In each of the years the p-value is considerably higher than 0.05 .

\section{Conclusions}

The type and size of the costs is partly dependent on the financial strategy conducted by the enterprise. The relationship between cash and other current assets, such as an inventory, depends on the specificity of the enterprise. Enterprises operating in a situation of high uncertainty and risk will have relatively higher inventory resources - compared to the level of current assets in other firms from the same branch. Another element that may affect the growth of the average level of cash in the enterprise and increase their relative share in the structure of current assets is the amount of costs of transactions and the cost of capital. Generally, it is recommended that the level of each of these current assets (i.e. cash, inventories and receivables) was analyzed separately. The percentage of the cost of inventory maintaining comes from the fact that the cost of maintaining inventories grows in proportion to the level of stocks in the enterprise. This share is the sum of the opportunity costs (equal to the cost of capital financing enterprise), the costs of storage, handling and internal inventory transport, insurance and stocks perish. Hence the percentage of the cost of maintaining inventory is usually higher than the cost of capital financing of the enterprise, taken as an alternative cost seen as cost of capital that consumes the efficiency of the enterprise. In e-commerce firms such a relation plays a key role. Our results have presented that in Table 2 and Figure 1. The level of inventories has a large significance for the profits and losses of e-commerce companies. Nevertheless, the profits of companies selling online do not differ significantly on the background of the entire industry. 


\section{References}

De Kare-Silver M. (2002). E-szok, rewolucja elektroniczna w handlu. Warszawa: PWE.

GUS, http://www.stat.gov.pl/gus/definicje_PLK_HTML.htm?id=POJ-5934.htm (10.09.2013).

Harwood T. (2012). Emergence of gamified commerce: Turning virtual to real. Journal of Electronic Commerce in Organizations, 10 (2), 16-39.

lo Storto C. (2013). Evaluating ecommerce websites cognitive efficiency: An integrative framework based on data envelopment analysis. Applied Ergonomics, 44 (6), 1004-1014.

Kraska M. (red.) (2004). Elektroniczna Gospodarka w Polsce - Raport 2004. Instytut Logistyki i Magazynowania, Poznań, http://www.logistyka.net.pl/images/articles/4473/raport_e-gospodarka2004.pdf (25.04.2016).

Lawrence J.E. (2013). Barriers hindering ecommerce adoption: A case study of kurdistan region of Iraq. Technology diffusion and adoption: Global complexity, global innovation (pp. 152-165).

Szopiński T. (2013). Czynniki determinujące korzystanie z handlu elektronicznego przez konsumentów. Handel Wewnętrzny, 6 (347), 32-42.

Żurak-Owczarek C. (2011). Technologie informacyjne determinantą współczesnego biznesu. Łódź: Wydawnictwo Uniwersytetu Łódzkiego.

\section{WPLYW POZIOMU ZAPASÓW NA ZYSKOWNOŚĆ PRZEDSIĘBIORSTW E-COMMERCE W POLSCE}

Streszczenie: $\mathrm{Cel}$ - Głównym celem artykułu jest dyskusja naukowa na temat wpływu zapasów na poziom zysków przedsiębiorstw prowadzących sprzedaż online w Polsce.

Metodologia/podejście - Procedura testowa opiera się na metodzie wielokrotnych badań studium przypadku. Przedmiotem badań są firmy, które sprzedają online w Polsce. Wykorzystano dane statystyczne i analizę finansową na podstwie dostępnych sprawozdań finansowych z bazy Amadeus. Osiągnięcie tych celów stosowano w badaniach literatury, polskiej i anglojęzycznej.

Wynik-poziom zapasów ma duże znaczenie dla zysków i strat spółek e-commerce. Zyski firm sprzedających w Internecie nie różnią się znacząco na tle całego przemysłu.

Oryginalność/wartość - Projekt może być wykorzystywane do budowania i oceny zagadnień naukowych związanych z integracją zarządzania struktury kapitału i innych kwestii związanych z zarządzaniem finansami w organizacjach. Przeprowadzone badania są istotne dla stosowania teoretycznych zebranych danych empirycznych w projekcie i mogą również służyć jako podstawa do skorygowania modeli zarządzania wydajnością w firmach. Badania będą miały na celu przyczynienie się do lepszego zrozumienia zagadnień związanych z wpływem czynników i określenia ich ekonomicznej efektywności.

Słowa kluczowe: e-commerce, sprzedaż online, internet, zarządzanie zapasami, przedsiębiorstwo

\section{Citation}

Michalski G., Brożyna E. (2016). The Impact of the Level of Inventories on Corporate Profits in E-Commerce Companies in Poland. Finanse, Rynki Finansowe, Ubezpieczenia, 4 (82/1), 159-165. DOI: 10.18276/frfu. 2016.4.82/1-13. 